\title{
THE IMPACT OF TRANSNATIONALIZATION ON THE GLOBAL CONSUMER MARKET
}

\author{
Tetiana Kniazieva' ${ }^{1}$, Anna Shevchenko ${ }^{2}$, \\ Hanna Radchenko ${ }^{3}$, Olena Komova ${ }^{4}$, Liliia Pankova ${ }^{5}$
}

\begin{abstract}
The study found that globalization has no effect on the content of monopoly capital, which has changed its form because of the existence of the process of transnationalization. The growth of transnational corporations not only increases the interaction with the state in the modern process of globalization. Minimization of negative consequences of transnational corporations in the consumer market, ensuring food security of the country involves the implementation of the strategy of import substitution and reasonable protectionism. This triggers the modernization of foreign economic strategies, improves institutional and organizational and economic efforts of state regulation to ensure protection of the borders of the consumer market. Here targets are defined: growth of own production; increase in investment demand; increase in non-resource exports through exports of high-tech, knowledge-intensive goods and services; intensification of measures within the system of comprehensive export support.
\end{abstract}

Key words: global economy, international complex, monopoly capital, transnationalization, structural transformation of the economy, globalization.

JEL Classification: A10, D11, D42

\section{Introduction}

The influence of the process of transnationalization on the functioning of developing consumer markets is an integral feature of the development of the world economy under conditions of globalization. Signs of globalization are manifested in the growing openness of states, liberalization of financial flows and national trade regimes, formation of the world consumer and financial market, international economic institutions, the world information network. Transnational corporations (TNCs), acting as a essential link in the development of international economic relations exerting a multidirectional influence on the functioning of the world economy and the state of economic entities, occupy special place in the system of modern globalized market. Appearing as a leader

Corresponding author:

${ }^{1}$ National Aviation University, Ukraine.

E-mail: tetiana.kniazieva@npp.nau.edu.ua

ORCID: https://orcid.org/0000-0002-4972-0055

${ }^{2}$ National Aviation University, Ukraine.

E-mail: anna.shevchenko@npp.nau.edu.ua

ORCID: https://orcid.org/0000-0002-7246-6964

${ }^{3}$ National Aviation University, Ukraine.

E-mail: hanna.radchenko@npp.nau.edu.ua

ORCID: https://orcid.org/0000-0003-4233-2831

${ }^{4}$ Kyiv National Linguistic University, Ukraine.

E-mail: lesika551@gmail.com

ORCID: https://orcid.org/0000-0001-6689-5140

${ }^{5}$ National University of Life and Environmental Sciences of Ukraine, Ukraine.

E-mail: lirochka@bigmir.net

ORCID: https://orcid.org/0000-0001-7933-8765 in globalization, they have become systemic factors of global development, which have an increasing influence on the functioning of the world economy, specific economic actors (Akman et al., 2017; Krupiak, 2017).

The modern system of the world order is such that the influence of TNCs on the evolution of national economies and the security of states has both positive and negative consequences. They provide an increase in growth rates, production efficiency, implementation of the investment regime, a qualitatively new level of security, which affects the degree of economic stability of countries, leveling their technological lag, changing the advanced technology on a global scale (Korolova et al., 2020). At the same time, financial power allows TNCs to displace national producers 
from the most profitable sectors of the economy, occupy significant segments of the consumer market, expand their own presence at the expense of imposed institutionalization, and act as a source of contradictions and negative socio-economic processes.

The relevance of the research is due to the fact that TNCs are a complex phenomenon, constantly evolving in the system of world economic relations, requiring the study of their essence, identifying the counteraction of significant influence, finding tools, mechanisms of national and international control over the activities of transnational corporations in the emerging consumer markets (Momot \& Avanesova, 2016; Bohdan et al., 2019).

The studies of economists of different times focus on the theoretical foundations of TNC development without taking into account the influence of contradictions and institutional contradictions related to their functioning. The nature of TNC expansion, changes in the profile of their activities, factors determining these processes in the aspect of national specifics of the countries are poorly studied and presented in the literature. The potentially possible positive and negative aspects of the impact of transnationalization on the Ukrainian consumer market as a subsystem of the world market are not fully covered, therefore, there is a need for theoretical studies that analyze its status and prospects of functioning (Pelekh, 2018; Samilyk et al., 2019).

The aim of the study is to identify trends, contradictions and features of TNCs expansion, arguments for strengthening their influence on the Ukrainian consumer market, to determine the content blocks of directions of its adaptation to the process of transnationalization, taking into account the target indicators of functioning, institutional aspects of regulation, priority areas of state protection, export-oriented activities and import substitution.

In accordance with this purpose, one can formulate the following research objectives:

- on the basis of the analysis of transnationalization, its essence and forms, to reveal the general laws of the expansion of transnational corporations, to substantiate it as an objective process of development and the factor of globalization;

- to determine the reasons, scale and directions of expansion of TNCs to emerging markets, considering the essence, dual nature and goals of functioning;

- to identify the main contradictions and trends in the introduction of TNCs in consumer markets in developing countries;

- to argue the significance of foreign economic expansion of TNCs as an objective factor of development, to evaluate their influence on the structure and dynamics of the consumer market of Ukraine as a subsystem of the world market. The object of research is the modern TNCs, trends and indicators of their activities in the world consumer market (Huntington, 2011).

The methodology of the research includes the results of developments in the works of foreign scientists who studied the phenomenon of transnationalization of emerging markets as subsystems of the world market, the problem of contradictory impact of foreign economic expansion of TNCs on the consumer market in a globalized environment. In the process of solving the tasks set, general scientific methods were used: dialectical, system-functional, structural-level, theoretical, monographic, as well as other scientific methods: logical, analytical, comparative, graphic and tabular interpretation of data (Baccini, 2012).

The working hypothesis of the study is to assume that the consumer market of Ukraine, as a subsystem of the world market in terms of its openness, is objectively inclined to influence the process of transnationalization, which manifests itself in the contradictory, dualistic effect of TNCs, which determine the structural, volume and sectoral transformation of the market, reproduced in its quantitative and qualitative indicators, uneven functioning, which requires its balance on the basis of institutional regulation and improvement of the state defense system. The degree of certainty and validity of scientific statements, conclusions and recommendations is confirmed by the generalization of the experience of TNC expansion into emerging markets, using modern methods of scientific analysis of world economic processes, testing in scientific discussions and the practice of transnationalization of the consumer market.

\section{Understanding the manifestations of economic globalization}

Different categorical interpretations of globalization are presented in scientific publications, but the only common interpretation is absent. The most common is the understanding of the manifestations of the globalization of the economy through such processes as: increasing interdependence and the relationship of international economic relations, increasing their scale; the conventionality of borders between national economic relations and international ones; Inclusion in the global system of virtually all states. The category of "TNC" is based, first of all, on the wording of international organizations. Thus, UNCTAD (The United Nations Conference on Trade and Development, 2020), originally from TNCs, represented firms consisting of parent companies and their affiliates abroad, provided that the former controlled the activities of established affiliates whose shares were determined at a level not less than $10 \%$ in share capital. Transnational corporations as a result of scientific and technological revolution 
are one of the most interesting phenomenon of modern global economy (Šaková, 2004).

As a consequence, UNCTAD identified new criteria for the inclusion of a firm in the category of TNCs, which resulted in clarification of the wording. Thus, TNC is a company with divisions in two or more countries, conducting a coherent policy with one or more decision-making centers. At the same time, the ability to control the assets of other economic entities in the countries of base, remains in the parent company, usually with the participation of capital. New branches and enterprises can be created overseas through direct investments, which turns the company into a transnational one. The lower limit of participation in capital is $10 \%$, which is defined as a sufficient condition for establishing control over the assets of subsidiaries. As a result, the number of TNCs increased by an order of magnitude in the global economy (Antropova et al., 2015).

Nowadays, the largest number of multinational corporations is registered in developed countries, for example it is China. Also most of the leading TNCs are located in North America, then Europe and Asia and Russian TNCs occupy only $3 \%$ of the list (Astrakhantseva et al., 2019). According to Forbes, the top ten largest TNCs in the world in 2018 included: seven banking institutions, four of which were Chinese companies (China Construction Bank Corporation, Bank of China, JPMorgan Chase, Bank of America, Agricultural Bank of China, ICBC Wells Fargo), an American multi company in the USA. (Apple) and other Chinese insurance company (The World's Largest Public Companies, 2020). Among modern approaches to TNCs, Henry Dunning's Theory of Investment Development Path (IDP) is of particular importance. It argues that the level of economic development of countries is related to the degree of maturity of its enterprises, the volumes of participation in the international flow of capital. In his theory, there are five levels of economic development of countries, which corresponds to the degree of evolution of TNCs, the relationship between exports and imports of foreign direct investment. They differ in the following points:

1. At the first level, the economies of countries are underdeveloped, there are no conditions not only for the accumulation and export of investments, but also their imports, except for those who have significant reserves of natural resources.

2. At the second level, the economy of countries is characterized by a tendency of growing GDP - up to 2.5 thousand dollars per capita. Due to this expanding domestic demand in the consumer market. By attracting foreign TNCs who want to conquer foreign markets, imports of foreign direct investment are increasing. However, the level of development of national enterprises is still low, which does not contribute to the export of investments, and if it exists, it is oriented mainly to regional markets or countries with similar economic development.

3. In countries of the third level, 10 thousand dollars of GDP per capita is provided. Import of investments are slowing down against the backdrop of increased exports, as TNCs enter into tough competition with national companies, indicating the preconditions for the creation of the first national TNCs. However, as before, the amount of accumulated investment with import is more than their export volumes.

4. At the fourth level, GDP is 10-36 thousand dollars per capita. The country shows growth in national TNCs, and exports exceed imports of foreign direct investment.

5. At the fifth level, according to some economists, is the US economy, which has the largest number of TNCs, and the volume of imports and exports of foreign direct investment is actually balanced (Khalatur et al., 2018).

Thus, this theory argues that the number of TNCs created in the country is a kind of indicator of the level of surplus investment in one or another field of production and the overall degree of economic development. By increasing the import of foreign direct investment, the effect of "swelling of investment demand" in various economic sectors is created, which stimulates the growth of national investment exports.

\section{The regularity of foreign economic orientations in the process of transnationalization}

TNC means a large corporation that implements trade, investment, production-technological and integration ties with firms in two or more countries, which significantly affects the performance of a specific industry where TNC operates. It is assumed in some cases the need for their presence in no less than 6 countries.

Agreeing with this interpretation, we can formulate that the transnational corporation is a form of development of monopolistic capital. In this sense it bears all the features and contradictions of the monopolistic form of capital in general. However, it is obvious that it has a number of new features, that in this form monopoly has undergone a number of modifications, has acquired new features and characteristics (Grigoreva \& Garifova, 2015).

Thus, modern TNCs are gigantic industrial and financial associations that are international in scope based on the principles of centralized planning and corporate governance on a global scale, implementing a policy in international trade aimed at expansion. Also, TNCs are based on industrial and scientific- 
technical cooperation, technology exchange and capital investment, labor force migration, which deepen the process of internationalization, taking into account the objective tendencies of the international division of labor, and determine its new schemes (Becker-Ritterspach et al., 2017).

Consequently, TNCs are characterized not only by contradictions inherent in monopolistic capital in general, but also by special ones generated by this form of association. The question of the relationship between transnationalization, through the expansion of TNCs, and the deepening contradictions of modern capitalism is related to a number of new relations in the world economy, the theoretical understanding of much of which has not given unambiguous estimates in the literature. Part of these new ties and trends in the development of TNCs were not considered at all. Therefore, the specification of the theoretical and methodological position, which is the initial, basic for the analysis and conclusions regarding the transnationalization and deepening of the contradictions of capitalism in the conditions of globalization, becomes of special significance.

The essence of all forms of monopolistic unions is always the same, it is a conspiracy for the economic achievement of its dominant position. These forms differ according to the mechanism of economic realization of their monopoly position. In this sense, the concern differs from cartels, syndicates, trusts. Therefore, TNCs do not differ from the concern as a form of movement of monopoly capital. Having entered the international environment, TNCs do not lose any features of a concern in the form of a monopoly. Moreover, it broadens its reproduction on the path of transnationalization, using the mechanism of the concern - the "system of participation", which allows to establish financial control over huge capital.

The predominant way of international expansion of TNCs is through mergers and acquisitions through the purchase of controlling stakes. Thus, monopolies in the form of the concern and TNCs in the way of establishing economic domination are the same type, and, therefore, there are no grounds in considering TNCs as a new form of a monopolistic association. At the same time, uniformity does not mean their identity. TNC is a modified form of the concern, it has a number of specific characteristics (Koldovskiy \& Chernega, 2018).

Although the formation of TNC does not change the fundamentally universal connection in the system of modern capitalism, it nonetheless informs it of new elements, substantially modifying it. This is precisely what it means:

- there is a number of new qualities in the movement of corporate property;
- there are new qualities in the production and sale of additional value and profit;

- the scientific and technical base of the monopoly is growing sharply;

- TNCs generate new forms in the system of relations between monopolistic industrial associations and banks;

- the adaptive properties of the market system are sharply intensifying with the advent of TNC, its adaptation to the new conditions in the world, expanding the possibility of increasing the exploitation and looking for new forms.

There are differences and peculiarities between TNCs of different states in the intensity of expansion, its scale, due to differences in levels of concentration and centralization of capital in different countries. In particular, Western European monopolies inferior to the United States' in terms of concentration of production and capital, in terms of profit. Only by the degree of concentration employed in the largest enterprises they surpass them (Bazhanov et al., 2019).

Thus, the clarification of the question of differences between TNCs is based on one of the most important principles of materialist dialectics - the principle of the relationship of general, special and individual. Relying on this principle allows us to conclude, firstly, that the only essential characteristic of TNCs is determined primarily by the socioeconomic environment in which they are formed and operating and by the system of objective economic laws and regularities inherent to it (unevenness development, fierce competition and so on). Secondly, this approach allows us to conclude on a number of specifics of TNCs that are determined by the regional, sectoral specificity and country of origin (Obolenska et al., 2019).

Consequently, transnationalization is a process of quantitative and qualitative growth of TNCs, expansion and strengthening of their activities in the conditions of globalization. It is a rather controversial phenomenon, since the balance of positive and negative effects, shifts towards the last of them, in the technological, economic, political and social development of countries. The growing openness of the emerging economies, the internationalization of the functioning of national economic entities determines the definition as an independent sphere of theoretical analysis and practical knowledge of the influence of TNCs on the dynamics of the consumer market, which represents the organic interaction of the totality of institutions, elements and subjects of the process of commodity exchange (Assche, \& Gangnes, 2019).

Structural and functional contradictions, crisis and conflict situations, which distort and inhibit the processes of monopolistic capital accumulation, determine and support high rates of TNC penetration 
Table 1

Trends due to transnationalization

\begin{tabular}{|l|l|}
\hline \multicolumn{1}{|c|}{ Period } & \multicolumn{1}{c|}{ Trends } \\
\hline $\begin{array}{l}70-80 \text { years } \\
\text { of XX centurty. }\end{array}$ & Activation of export of capital from developing countries \\
\hline $80^{\text {th }}$ years of XX century & $\begin{array}{l}\text { 1. Capital outflows from developing countries: the emerging industrialized countries of East and Southeast } \\
\text { Asia (Hong Kong, Singapore, South Korea, Taiwan) are due, first, to the region's declining attractiveness } \\
\text { for MNCs due to rising wages and, second, to an increase in their industrial exports. } \\
\text { 2. Reorientation of the sectoral structure of capital exports, investing in manufacturing, finance, and services. }\end{array}$ \\
\hline $1983-1986$ years & $\begin{array}{l}\text { The balance of U.S. investment is worsening because of the slowdown in U.S. exports and the growth } \\
\text { of imports of foreign capital into the country. }\end{array}$ \\
\hline $\begin{array}{l}90^{\text {th }} \text { years of XX century } \\
\text { End of XX - beginning } \\
\text { of XXI century }\end{array}$ & $\begin{array}{l}\text { The regrouping of foreign investment in favor of developed countries, caused by the huge debt of the } \\
\text { Third World, is complicated by its repayment. }\end{array}$ \\
\hline Beginning of XXI century \\
$\begin{array}{l}\text { Formation and activation of the emerging industrial countries of Southeast Asia, the Latin American countries } \\
\text { and a number of Middle East countries in the global economy. }\end{array}$
\end{tabular}

Source: systematized by the authors

into developing markets. The analysis of sectoral, sectoral and structural transformation of developing economies allowed us to systematize a number of new trends in the expansion of TNCs (Table 1).

Thus, the analysis of the historical development of TNCs showed that the evolution of TNCs is closely linked with a sharp escalation of internal contradictions of capitalism at the end of the XX century. Their nature regarding expansion appears both on the national and international levels. All indicators in the statistical reporting of TNCs grow, (volume of FDI and retail sales, assets, profit, capitalization). An analysis of the trend of transnationalization shows the extent and directions of the expansion of TNCs into the consumer markets of developing countries, the distribution of natural, productive, financial and human resources, which suggests the formation of contradictions and new conflicts in the modern world economy (Figure 1).

An assessment of the causes, scales and tendencies of TNC expansion shows that under the conditions of globalization, the essence of monopoly capital does not change. TNCs expand the boundaries of their domination. Their activities, the impact on the development and security of emerging economies

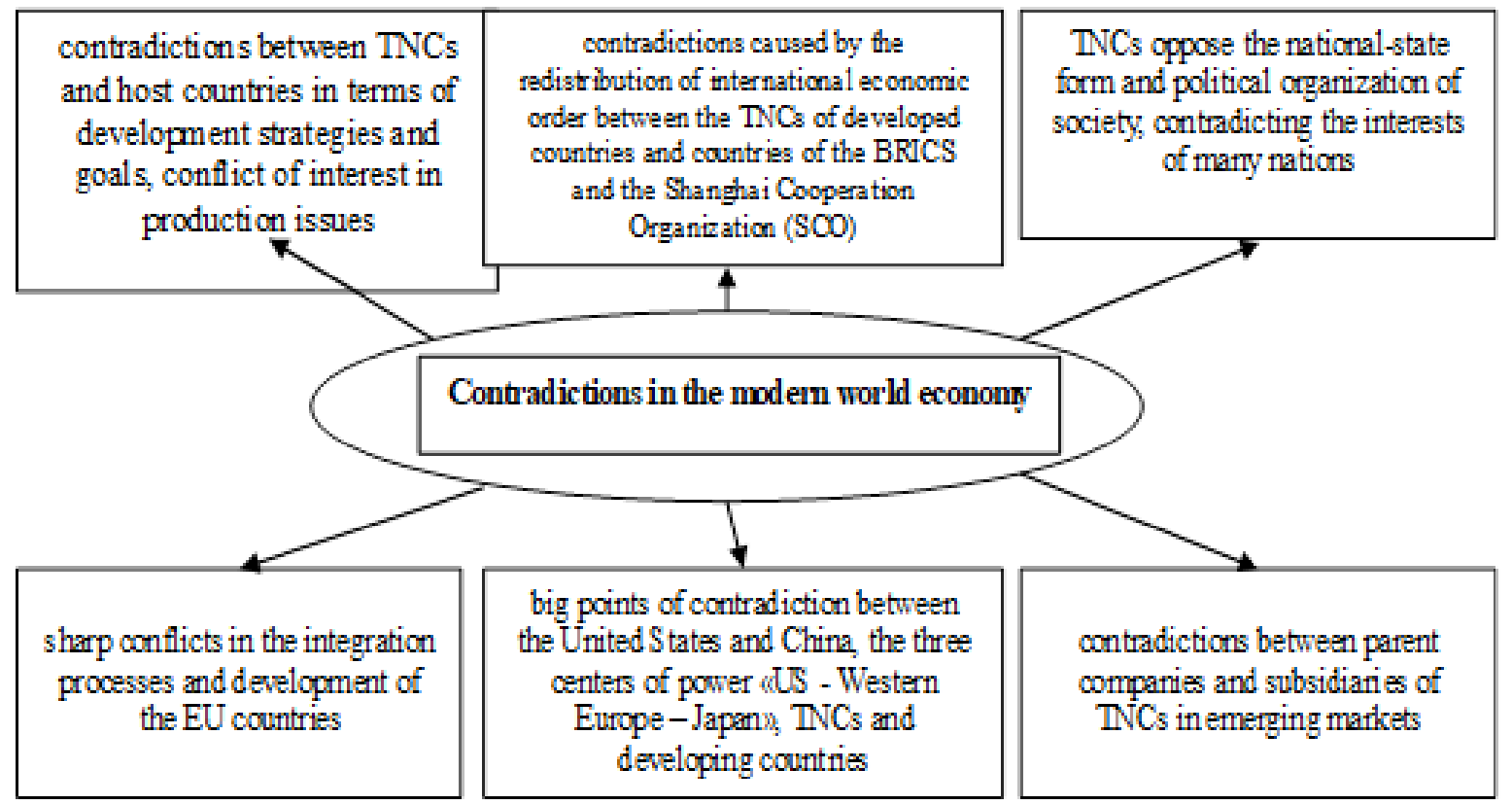

Figure 1. Contradictions in the modern world economy

Source: systematized by the authors 
are heterogeneous, has a dual meaning. On the one hand, TNCs are the main structure-creating link of the economy, the leading force in the country's development and the growth of production efficiency. On the other hand, they are the generator of a number of negative socio-economic processes. However, the general vector is that TNCs provide stable economic ties between different subsystems and countries, forming a single global economy. The trend of world development is characterized by increased concentration of production and capital, both at the micro level of enterprises, and on the megalevel of transnational corporations (Anderson \& Cavanagh, 2000).

\section{Adaptation of the consumer market to the process of transnationalization}

The transnationalization of the Ukrainian consumer market is an objectively necessary and prepared strategic step for globalization, without which it would not be possible to form a developed economic system of the country, to ensure its competitiveness and efficiency. The systematization of trends and features of the consumer market functioning under the influence of foreign economic expansion of TNCs indicates the transformation of its volumes, structures and boundaries as a complex mechanism of interaction of social, economic, political, institutional elements and subjects of the process of commodity exchange (Table 2).

The expansion of TNC, on the one hand, has had a positive impact on consumer preferences and foreign economic activity of enterprises: the pace of "innovative economy"; the emergence of new products and industries (40-60\% of turnover of successful companies is due to the goods introduced to the market in the last 5-7 years); use of information technology and e-commerce; reduction in the cost of communications; development of network organizations; eliminating trade barriers; the importance of international and individual marketing. On the other hand, the losses are borne by domestic commodity producers, because the activities of TNCs are aimed at improving their own financial condition (production growth, profit capitalization), asset growth, and further expansion. Therefore, the strategic direction of development of Ukrainian companies should be: concentration and diversification of production activities on the basis of product and geography, expansion of the range of products, continuous development of new products and innovative technologies, considering the priorities of the national producer and consumer, the formation

Table 2

The main trends in the Ukrainian consumer market

\begin{tabular}{|c|c|}
\hline Trends & Content and features \\
\hline $\begin{array}{l}\text { Movement towards structural and } \\
\text { sectoral stabilization }\end{array}$ & $\begin{array}{l}\text { Changes in the structure of domestic consumption and production, increasing requirements for } \\
\text { the quality of goods and food products, the increase in their volume involves the formation of the } \\
\text { boundaries, capacity and scale of the domestic market, taking into account participation in the } \\
\text { international division of labor and trade flows of international trade. }\end{array}$ \\
\hline $\begin{array}{l}\text { Changing the institutional and } \\
\text { organizational structure }\end{array}$ & $\begin{array}{l}\text { The formation of a fundamentally new institutional, organizational and legal structure and } \\
\text { infrastructure with an orientation on the practices and technologies of developed countries, adequate } \\
\text { to the current state of the world market. }\end{array}$ \\
\hline $\begin{array}{l}\text { Real transition from raw material } \\
\text { export-oriented policy to import } \\
\text { substitution }\end{array}$ & $\begin{array}{l}\text { The gradual shift away from raw materials policy in the international division of labor is outpacing } \\
\text { the growth of international trade in processed and ready-to-consume goods and food rather than in } \\
\text { raw materials and products. }\end{array}$ \\
\hline $\begin{array}{l}\text { Change of position in global } \\
\text { commodity flows and the ranking of } \\
\text { world exporters }\end{array}$ & $\begin{array}{l}\text { Redistribution of volumes and geographical directions of exports and imports of certain food and } \\
\text { non-food products to developing countries of East Asia and Eastern Europe }\end{array}$ \\
\hline $\begin{array}{l}\text { Overcoming the current distortions } \\
\text { of the consumer market in terms of } \\
\text { volume and structure }\end{array}$ & $\begin{array}{l}\text { Creation of a unified and effective mechanism of state and legal regulation of the market, because } \\
\text { the integration of firms under the influence of TNCs covers all major areas of life: social, economic, } \\
\text { innovative, institutional }\end{array}$ \\
\hline $\begin{array}{l}\text { Modification of the concept } \\
\text { of production and market } \\
\text { competitiveness under the influence } \\
\text { of transnationalization }\end{array}$ & $\begin{array}{l}\text { Due to the deterioration of Ukraine's position in the ranking of world exporters due to the decline in } \\
\text { exports of traditional goods, against the background of a weakened economy and military actions. In } \\
\text { this regard, it is necessary to take into account national preferences and development factors, in the } \\
\text { context of increased global competition under the influence of TNCs, the deterioration of the global } \\
\text { food market, the volatility of prices and national currencies. }\end{array}$ \\
\hline $\begin{array}{l}\text { Ensuring national economic security } \\
\text { through a set of measures }\end{array}$ & $\begin{array}{l}\text { Implementation of mergers and acquisitions, taking into account national interests, protection of the } \\
\text { interests of shareholders and investors, openness and transparency, convergence of business value } \\
\text { and value of company assets. Development of the domestic light, food, processing industry and } \\
\text { agriculture (at the level of organizations, regions and countries); improvement of state regulation of } \\
\text { foreign trade in the sphere of supply (at the country level). }\end{array}$ \\
\hline
\end{tabular}

Source: compiled by the authors 
of stable market boundaries and the efficiency of its functioning (Kaleka \& Morgan, 2019).

Embedded in global commodity flows, the consumer market is undergoing a structural transformation under the influence of MNCs, geopolitical changes, and the realignment of power between dominant countries and regional groupings. Its functioning and growth rates were influenced by the diverse dynamics of the largest economies and the world market - the crisis processes in developed countries in 2013-2017; the trend of a decrease in world prices and value of trade, due to aggravation of the geopolitical situation and the situation of raw commodity markets; institutional barriers in EU countries.

The consumer market has lost its leading positions, which is characterized by a decrease in volume and changes in the structure of retail trade, a deterioration in the quality and range of goods and services offered, the departure of a number of manufacturers, well-known brands, a drop in profits and profitability of trade organizations. Increased competition and monopolization in the retail market under the influence of the escalation of retail networks, which have large-scale resources and squeeze out weak business participants (Grigoreva \& Garifova, 2015).

We suggest to consider the experience of Asian countries. For example, Vietnam's enterprises still depend on input sources from China. General Department of Vietnam Customs statistics showed that last year, from the total import value of $\$ 253.07$ billion in 2019, the import value of 7 key commodity groups from China was $\$ 56.73$ billion, of which import of computers, electronic products and spare parts worth $\$ 12.11$ billion USD; chemical products - $\$ 3.23$ billion, mobile phones and accessories - $\$ 7.58$ billion, machinery and equipment, - \$ 14.9 billion; textile, garment, leather and footwear materials and accessories of all types - \$ 11.52 billion; plastic materials and products - $\$ 3.99$ billion; iron and steel of all kinds-\$3.4billion. Unfortunately, COVID-19pandemic has disrupted imports from China and other countries into Vietnam (Lam et al., 2020).

Thus, much of what is exported from our country is raw materials and goods with low added value. Expansion of TNCs without government intervention leads to unstable functioning of the consumer market, loss of state sovereignty. The index of food imports exceeds the permissible values of the country's economic security. The share of foreign capital in the food industry is $60 \%$ and continues to grow. The country does not provide itself with products of its own production. For the development of the economy taking into account internal interests, it is necessary: activation of the introduction of
TNCs, operating in the sphere of manufacturing industry; creation of joint research enterprises with participation of them, for development and reception of the newest technologies and goods; a reorientation to restructuring and modernization of industries with a long payback period (e.g., machine building), due to the unevenness of investments by industries; the expansion of agricultural co-operation in the country as an instrument for protecting farmers from the expansion of TNCs; development of own domestic brand (Jaworek \& Kuzel, 2015).

For this purpose it is practiced to create state corporations capable of competing with foreign MNCs, for example, a specialized state corporation in the agricultural sector. Through such an institution it is possible to ensure the development of "related clusters", plants for the production of agricultural machinery, fertilizers, etc. The chain will develop production clusters necessary for the functioning of related industries of the second level. In the long term, the economy can be restructured according to the innovation-technological type (Jaworek \& Kuzel, 2015).

\section{Conclusions}

On the basis of the analysis of indicators of activity of Ukraine and other countries in the world market and influence on economy expansion of TNCs it is possible to draw a number of conclusions. Transnationalization is a process of quantitative and qualitative growth of TNCs, expansion and strengthening of their activity in the conditions of globalization. This is a contradictory phenomenon, since the balance of positive and negative effects in the technological, economic, political and social development of countries is shifted towards the latter.

Openness of developing economies, internationalization of national economic entities, deepening of the international division of labor cause increased influence of TNCs on the dynamics of the consumer market, which is an organic interaction of a set of institutions, elements and subjects of the exchange of goods.

The growing presence, the massive invasion of international business and national markets, like all processes in the global economy, is contradictory and dual in nature. On the one hand, the expansion of TNCs provides external impulses and incentives for production in the host countries, contributes to the deepening of the division of labor, specialization and cooperation. On the other hand, the inevitability of numerous negative consequences due to the monopolistic form of these processes. Further, on the one hand, external expansion promotes the emergence of large international complexes, the functioning of integrated production systems, but, on the other hand, 
the monopolistic form of their organization ensures the creation of an integral system of corporate dominance in the global economy. The largest number of TNCs belongs to developed countries. This indicates an overcapacity of domestic investment, a surplus of capital flows outside national economies. It is important to note that COVID-19 should be seen as a major stagnation of globalization over the decade. No proper lessons have been learned from the previous financial crisis, so perhaps that is why the detrimental effects of COVID-19 have been even more pronounced. Today, the coronavirus pandemic is having a widespread negative impact on trade and foreign investment, with a consequent reduction in global exports and imports in a number of sectors. In addition, the short-term adaptation to contain and reverse the worst effects of MNCs in the current crisis is an opportunity to reflect on international business policies and business models, it has been shown that the Pandemic reinforces a type of narrowminded nationalism that seemed to have disappeared.

The general vector and direction of evolution is that TNCs provide sustainable economic links between different subsystems and countries, thus integrating national economies into a single world economy. The trend of global development is characterized by increasing concentration of production and capital, both at the micro level of enterprises and at the mega level of transnational corporations.
The expansionist activities of TNCs in the Ukrainian consumer market are complex and contradictory. In general, they have a positive impact on economic development, but are focused on improving their own financial condition (increasing production volumes, capitalization of profits) and further development of the company. Therefore, without government intervention, TNCs' expansion leads to a loss of state sovereignty, which undermines the country's national security.

TNCs have transformed the sectoral structure of the market and production, changing the flow of goods from Ukraine, which is determined by its place in the modern international division of labor and production specialization. Uneven development of the consumer market under the influence of TNCs is manifested in regional, structural, sectoral transformations, changes in the competitive environment, through a gradual increase in capital and assets, reunification, achieved through mergers and acquisitions.

In the Ukrainian consumer sector, retail trade and agriculture there are active transformation processes. Therefore, a set of government measures in the field of industrial and structural policy aimed at accelerating the growth of domestic production, the formation of stable boundaries of the Ukrainian consumer market and improve the efficiency of its functioning.

\section{References:}

Akman, M., Berger, A., Dadush, U., Evenett, S., Johnson, L., Mendez-Parra, M., Ochoa, R., \& Schmucke, C. (2017). Key Policy Options for the G20 in 2017 to Support an Open and Inclusive Trade and Investment System. Available at: http://hdl.handle.net/11540/6922

Anderson, S., \& Cavanagh, J. (2000). The Rise of Corporate Global Power. Institute for policy studies. Available at: http://s3.amazonaws.com/corpwatch.org/downloads/top200.pdf

Antropova, T. G., Ishmuradova, I. I., Minsabirova, V. N., Gazizova, F. S., \& Temirbulatov, R. R. (2015). Economic security in the conditions of innovative transformation of economy. Review of European Studies, no. 7(1), pp. 195-199.

Assch, A., \& Gangnes, B. (2019). Global value chains and the fragmentation of trade policy coalitions. Transnational Corporations, no. 26(1), pp. 31-60.

Astrakhantseva, E., Shipshova, O., \& Antonova, M. (2019). The role of transnational corporations in the globalization of the economy. Advances in Social Science, Education and Humanities Research, no. 364, pp. 1-5.

Baccini, L. (2012). Preventing protectionism: international institutions and trade policy. Review of International Organizations, no. 7(4), pp. 369-398.

Bazhanov, V. O., Bazhanova, V. O., Kachur, V. O., Pankova, L. O., \& Pushkar, M. V. (2019). The right to artistic freedom in Post-Soviet countries. Asia Life Sciences, no. 2, pp. 881-896.

Becker-Ritterspach, F., Lange, K., \& Becker-Ritterspach, J. (2017). Divergent patterns in institutional entrepreneurship of MNCs in emerging economies. Critical Perspectives on International Business, no. 13(3), pp. 186-203.

Bohdan, S., Vitalii, K., Taras, H., Dmytro, Z., \& Serhii, K. (2019). Historical and legal analysis of development of administrative responsibility for unauthorized occupation of a land plot. Journal of Legal, Ethical and Regulatory Issues, no. 22(6), pp. 1-7.

Calabrese, A. (2012). Service Productivity And Service Quality: A Necessary Trade-Off? International Journal of Production Economics, no. 135, pp. 800-812.

Grigoreva, E., \& Garifova, L. (2015). The economic security of the state: the institutional aspect. Procedia Economics and Finance, no. 24, pp. 266-273.

Huntington, S. P. (2011). The clash of civilizations and the remaking of world order. New York: Simon \& Schuster. 
Jaworek, M., \& Kuzel, M. (2015). Transnational corporations in the world economy: formation, development and present position. Copernican Journal of Finance and Accounting, no. 4(1), pp. 55-70.

Kaleka, A., \& Morgan, N. (2019). How marketing capabilities and current performance drive strategic intentions in international markets. Industrial Marketing Management, no. 78, pp. 108-121.

Khalatur, S., Pavlova, G., \& Zhylenko, K. (2018). The role of some indicators of financial security in Ukraine in the context of transnationalization and national interests. Investment Management and Financial Innovations, no. 15(3), pp. 237-248.

Kharazishvili, M., \& Sukhorukov, A. (2013). On methodology for complex assessment of components of economic security of state. Strategic Priorities, no. 3(28), pp. 5-15.

Koldovskiy, A., \& Chernega, K. (2018). Modeling the Ukrainian consumption. Geopolitics under Globalization, no. 2(1), pp. 34-44.

Korolova, V. V., Dolianovska, I. M., Hryhorchuk, M. V., \& Vyshnevska, Y. V. (2020). Theoretical and practical aspects of counteracting unfair competition and violation of antimononpoly laws. International Journal of Criminology and Sociology, no. 9, pp. 1533-1541.

Krupiak, I. Y. (2017). Vektory zovnishnoyi torhivli derzhavy v umovakh suchasnykh ekonomichnykh peretvoren [Vectors of foreign trade of the state in the conditions of modern economic transformations]. Hlobalni ta Natsionalni Problemy Ekonomiky, no. 20, pp. 158-162.

Lam, T. S., Antipanova, O. A., Babyshev, V. U., Ngoc, T. T., Binh, D. T., \& Barysheva, G. A. (2020). Problem of multinational transnational corporations under COVID-19. In SHS Web Conf: XVII International Conference of Students and Young Scientists "Prospects of Fundamental Sciences Development", no. 80, pp. 01003.

Momot, T., \& Avanesova, N. (2016). Systematization of international experience of ensuring economic security of exacerbation of the threats and challenges of a new type for national and international security. Baltic Journal of Economic Studies, no. 2(1), pp. 77-83. DOI: https://doi.org/10.30525/2256-0742/2016-2-1-77-83

Obolenska, T., Shatarska, I., \& Shevtsov, Ye. (2019). The use of the "Rational" system of global marketing communications in management of international enterprises. Problems and Perspectives in Management, no. 17(3), pp. 14-30.

Pelekh, O. (2018). Evolyutsiya pohlyadiv na faktory ekonomichnoho rozvytku: novi teoretychni pidkhody [Evolution of views on the factors of economic development: new theoretical approaches]. Biznes Inform, no. 7 , pp. 8-14.

Šaková, B. (2004). Transnacionálne korporácie vo svetovej ekonomike. Bratislava: Ekonóm.

Samilyk, L. O., Maliarova, V. O., Dzhafarova, O. V., Gudz, T. I., \& Kovalchuk, V. B. (2019). Complementary medicine: international experience of functioning and specific features of the application in Ukraine. Wiadomosci Lekarskie (Warsaw, Poland: 1960), no. 72(5 cz 2), pp. 1103-1107.

The World's Largest Public Companies (2020). Forbes. Available at: https://www.forbes.com/ global2000/\#6a70007f335d

United Nations Conference on Trade and Development (2020). Investment Trends Monitor: Impact of the COVID 19 Pandemic on Global FDI and GVCs. Available at: https://unctad.org/system/files/official-document/ diaeiainf2020d3_en.pdf

Wilkins, M. (2001). The history of multinational enterpris. Oxford: Oxford University Press. 